this to the maker's discretion by allowing him not to produce it at the trial if he does not wish to. Finally, if the maker incurs expenses in defending the suit, or if his reputation suffers by reason of the bad faith suit, compensation may be allowed him in a tort action for wrongful civil proceedings which is now allowed in the majority of American jurisdictions, ${ }^{83}$ although a hard case to prove.

\title{
CONCLUSION
}

The confusion in the cases concerning acceleration clauses today is due to the attempts of the courts to solve these problems within the "time certainty" rubric of the NIL. This is unfortunate in that their reason for denying negotiability in many cases is their objection to the clause itself, although paradoxically the clause is almost invariably enforced, With this realization, the cases can be categorized according to the factual situation the clause describes. The more it portrays a pending inability on the part of the maker to pay, the greater the chance that the note will be held negotiable, and vice versa. ${ }^{84}$ Thus it seems that principles analogous to the doctrine of anticipatory repudiation are those used in deciding whether to impose the only sanction available under the NIL, non-negotiability. The Code recognizes that the problem is one of enforceability and provides that no acceleration clauses destroy negotiability ${ }^{85}$ It applies the doctrine in the case of power to accelerate "at will" or "when the holder deems himself insecure," only allowing exercise of the power in the good faith belief that the prospects of payment are impaired. This is a step forward as far as the Code expressly applies. It is urged that the Code be construed so as to forbid any acceleration if the facts relied upon to accelerate do not show an inability to pay, or an impairment of that ability, in the good faith belief of the holder.

\section{SEARCH AND SEIZURE UNDER THE UNIFORM CODE OF MILITARY JUSTICE}

The source and authority of the military law of this country is the Constitution which empowers Congress "to make Rules for the Government and Regulation of the land and naval Forces" and "to define and punish .. . Offenses against the Law of Nations," ${ }^{1}$ and constitutes the President

83. See Prosser, Torts 885-892 (1941).

84. Compare, however, the situations described in text at note 59 supra.

85. A big problem to corporations is to have their bonds drafted so that acceleration clauses, if any, do not destroy negotiability. Article III does not apply to investment securities (\$3-103(1)). Article VIII governs them, and problems of negotiability were thought to be of no more consequence; however, in response to the desire to make securities eligible for investments under certain state acts providing that, to be "legal," investments must be negotiable instruments, a new section [\$ 8105] has been proposed. That section reads: "(1) Securities governed by this Article are negotiable instruments." See Recommendations of the Editorial Board for Changes in the Text of the Uniform Commercial Code 14 (Dec. 29, 1952).

1. U.S. Const. Art. I, \& 8. 
as the Commander-in-Chief and makes it his duty to take care that the laws be faithfully executed. ${ }^{2}$ It also inferentially recognizes courts-martial by relieving these tribunals of the requirement of an indictment of a Grand Jury. ${ }^{3}$ The Uniform Code of Military Justice, ${ }^{4}$ establishing the present unified system of military law for the Army, Navy, and Air Force, was enacted by Congress on May 5, 1950.5 Pursuant to Article 36 of the Code, ${ }^{6}$ the President published the Manual for Courts-Martial, United States, $1951,{ }^{7}$ containing the procedure, including modes of proof and rules of evidence, for courts-martial. The United States Court of Military Appeals, consisting of three civilian judges, established by the Code for review of matters of law in court-martial cases has held that "the act of Congress (the Code) and the act of the Executive (the Manual) are on the same level" $s$ and "will be regarded as sharing a similar authoritative position." 9 This Note will examine the rules of search and seizure contained in the Mamual as applied and interpreted by the boards of review ${ }^{10}$ and the United States Court of Military Appeals. ${ }^{11}$

Affecting any discussion of admissible evidence is the introductory paragraph of the Rules of Evidence chapter of the Manual, ${ }^{12}$ which provides that the following sources of authority are to be referred to in the order given until a rule of evidence is found: the Mamual; the rules of evidence generally recognized in the trial of criminal cases in the United States district courts; and the common law. ${ }^{13}$ Prior to the Manual for Courts-

2. U.S. CoNsT. Art. II, §§ 2, 3.

3. U.S. Const. AMEND. V.

4. Hereinafter referred to as the Code and cited as U.C.M.J.

5. 64 STAT. $108-145$ (1950), 50 U.S.C. $\$ \$ 551-736$ (Supp. 1952), effective May 31, 1951.

6. 64 Stat. 120 (1950), 50 U.S.C. $\$ 611$ (Supp. 1952).

7. Hereinafter referred to as the Mamual and cited as M.C.M., 1951.

8. United States v. Lucas, 1 C.M.R. 19, 22 (Ct. of Mil. App. 1951). In subsequent citations the following abbreviations will be used: $C t$. of $M i l$. $A p p$. for Court of Military Appeals; $A$ for Army; $N$ for Navy; $A F$ for Air Force; $B d$. of Rev. for Board of Review; Jud. Council for Judicial Council; C.M. for Court-Martial; C.M.R. for Court Martial Reports; B.R. for Board of Review Reports. Also OSI for Office of Special Investigations; $C I D$ for Criminal Investigations Division; $M P$ for military police; JAG for Judge Advocate General.

9. United States v. Lonnenschein, 1 C.M.R. 64, 67 (Ct. of Mil. App. 1951).

10. All cases involving death, dismissal, discharge or confinement for one year or more must be reviewed by a board of review, composed of lawyers, which has authority to weigh the evidence, judge the credibility of witnesses, determine controverted questions of fact, and affirm only such findings of guilty and such sentences as it finds correct in law and fact and determines on the basis of the record should be approved. M.C.M., 1951, \100.

11. The Court of Military Appeals provides the last appellate review of courtmartial cases. It takes action only with respect to matters of law and it reviews all cases involving death, cases which the Judge Advocate General forwards to this Court and cases where the Court has granted review upon petition of the accused. For a discussion of the organization of the courts-martial system under the Code, see Mullally, Military Justice: The Uniform Code in Action, 53 CoL. L. Rev. 1 (1953).

12. M.C.M., 1951, c. 27.

13. This prescribed procedure was followed with approval by the Court of Military Appeals in United States v. Slozes, 1 C.M.R. 47, 51 (Ct. of Mil. App. 1951). 
Martial, 1949, no mention was made of searches and seizures and illegally obtained evidence in any courts-martial manual, although evidence obtained by illegal searches has been excluded from court-martial cases for a long time. ${ }^{14}$ Realizing the importance of the subject, the draftsmen of the Manual for Courts-Martial, 1951, which is the manual now in effect, set forth in greater detail the rules pertaining to the inadmissibility of evidence obtained as a result of an unlawful search and seizure and listed some examples of lawful military searches. ${ }^{15}$ These rules are patterned after the rules of search and seizure applied in our federal courts; however, there is an essential difference in their practical application. In the military system the power to determine whether a search should be made and the power to execute a search or direct its execution is in one person-the commanding officer. ${ }^{10}$ In civil jurisdictions the determination of what searches and seizures are permissible is made by a neutral and detached magistrate who has no power alone to execute a search.17

While in the early military cases ${ }^{18}$ the legality of a search was determined by deciding whether the accused's rights under the Fourth Amendment were violated, the recent cases ${ }^{10}$ emphasize that military personnel have no substantive constitutional right against unreasonable searches, but are protected only by procedural rules of evidence. ${ }^{20}$ In search cases not specifically covered by the Manual, reference must be made to the rules applied in the federal courts, which rules appear to be based on an exercise of judicial fiat.21 An accused has no remedy if the military appellate courts refuse to enforce the Manual or federal search rules, since the court-martial system is not part of the federal judicial system but is a separate and individual system of justice like that of the state courts. ${ }^{22}$ The rules of evi-

14. Digest of Opinions, JAGA 1912-1930 $\$ 1304(27)$ (1932).

15. M.C.M., 1951, II 152.

16. United States v. Florence, 5 C.M.R. 48, 51 (Ct. of Mil. App. 1952); United States v. Worley, 3 C.MI.R. (AF) 424, 442 (AF Bd. of Rev. 1950). This authority of the commanding officer is limited to property located within a military installation or property under the control of an armed force.

17. Johnson v. United States, 333 U.S. 10 (1948) ; United States v. Lefkowitz, 285 U.S. 452 (1932).

18. Digest of Opinions, JAGA 1912-1930 $\$ 1304(27)$ (1932); MENORANDUM OpINIONS, JAGA 1949-50 352 (1950).

19. United States v. Dupree, 5 C.M.R. 93, 96 (Ct. of Mi1. App. 1952); United States v. Kofnetka, 2 C.M.R. 773, 777 (AF Bd. of Rev. 1951).

20. Possibly this shift in attitude was occasioned by Supreme Court statements regarding the plenary powers of Congress over the armed forces and the Court's insistence that military personnel had to look to the military law for their due process. Creary v. Weeks, 259 U.S. 336 (1922) ; Hiatt v. Brown, 339 U.S. 103 (1950); Johnson v. Eisentrager, 339 U.S. 763, 783 (1950) ; Wurfel, Military Due Process, 6 VAND. L. REv. 251, 281 (1953).

21. See Periman, Due Process and the Admissibility of Evidence, 64 Harv. I. Rev. 1304, 1306 (1951) ; Comment, 58 YALE L.J. 144 (1948). Any constitutional authority upon which the federal rules regarding searches might be based, inure to military personnel by indirection in those cases not covered by the Mamlal. See text at note 13 supra.

22. In re Vidal, 179 U.S. 126 (1900) ; Altmayer v. Sanford, 148 F.2d 161, 162 (5th Cir. 1945). 
dence pertaining to searches and seizures established by the Supreme Court under its supervisory power over the federal judicial system cannot be used to permit the federal judiciary to control the admission of evidence in the state courts. By analogy, it is reasonably certain that no such control exists over the courts-martiai. ${ }^{23}$ Resort to a review by habeas corpus of a court-martial conviction based upon evidence procured by an illegal search and seizure should prove futile since the only question on such review is whether the court-martial had jurisdiction. ${ }^{24}$ Certainly a violation of a procedural rule of evidence would not be such a gross violation of an accused's rights so as to give rise to a defect in the jurisdiction of the court-martial. $^{25}$

\section{Evidence InADMSSIbLe UNder the Manual}

\I 152 provides that:

"Evidence is inadmissible against the accused if it was obtained as a result of an unlawful search of his property conducted or instigated by persons acting under authority of the United States, or if it was obtained under such circumstances that the provisions of Section 605 of the Communications Act of $1934,{ }^{26}$. . . pertaining to the unauthorized divulgence of communications by wire or radio, would prohibit its use against the accused were he being tried in a United States district court. ${ }^{27}$ All evidence obtained through information supplied by such illegally obtained evidence is likewise inadmissible. ${ }^{28}$ For example, evidence obtained by a lawful search is inadmissible if that search was conducted because of information derived from a preceding unlawful search of the kind mentioned above." 29

23. Even if this rule of evidence is grounded upon the Fourth or Fifth Amendments, since these amendments do not directly apply to the states, the rules of evidence based on the Fourth Amendment can not be forced on the states. Similarly, since the Fourth or Fifth Amendments do not apply to the military, the same result obtains.

24. Snedeker, Habeas Corpus and Court-Martial Prisoners, 6 VAND. L. REv. 288,295 (1953). The jurisdiction of a court-martial is conditioned upon the following requisites : that the court-martial was properly constituted, that it had jurisdiction over the accused and the offense with which he is charged; and that the sentence was one authorized by law. See Hiatt v. Brown, 339 U.S. 103 (1950) ; Johnson v. Eisentrager, 339 U.S. 763 (1950).

25. Accord, Hiatt v. Brown, 339 U.S. 103, 110 (1950).

26. 36 Stat. 1103 (1911), as amended, 28 U.S.C. $\$ 391$ (1946).

27. This provision was based on Nardone v. United States, 308 U.S. 338 (1939). See Legal and Ilegislative Basis, M.C.M., 1951240.

28. This provision stemmed from the rulings of the Supreme Court in Silverthorne Lumber Co. v. United States, 251 U.S. 385 (1919) and Gouled v. United States, 255 U.S. 298 (1921). See United States v. Rhodes, C.M. 354858 ( $\AA$ Bd. of Rev., Sept. 8, 1952). The rule should not be confused with that applying to involuntary confessions. M.C.M., 1951, I1 140a expressiy adopts the majority rule by providing that the circumstance that an involuntary admission or confession "furnished information which led to the discovery of pertinent facts will not be a reason for excluding evidence of such pertinent facts."

29. This section of the Manual further provides that, since courts-martial have no authority to order a return to the accused of illegally seized evidence or to im- 
Searches Without Authorization.-No definition of an unlawful search is given in the Manual, but the applicable rule is theoretically that imposed by federal court decisions which are grounded upon the constitutional prohibition against "unreasonable searches." 30 The Court of Military Appeals, accepting the principle that the fundamental inquiry is whether the search is unreasonable, expressly adopted ${ }^{31}$ the Supreme Court's view that "what is a reasonable search is not to be determined by any fixed formula" but "must find resolution in the facts and circumstances of each case." 32 However, the Court of Military Appeals appears willing to find "reasonableness" in situations never indorsed by the federal courts or the boards of review..$^{33}$ In United States $v$. Doyle ${ }^{34}$ a Navy master-at-arms (a noncommissioned officer assigned under the executive officer for the maintenance of good order and discipline) had been previously informed by a seaman that accused, who had been arrested earlier in the day as a result of another incident, had in his locker a pair of the seaman's shoes. The Court of Military Appeals found that under those circumstances the master-at-arms' action in searching accused's locker without the commanding officer's authorization was reasonable under existing military and navy law. The court stated that since an eyewitness had informed the master-atarms that accused had in his possession the clothing of another, there was reasonable and probable cause to believe that an offense had been committed by petitioner. The three federal cases cited by the court for this proposi-

pound such evidence, objection is properly made at the time the prosecution attempts to introduce such evidence. This makes inapplicable the rule originally applied by federal courts that a proper motion to suppress illegally obtained evidence must be made prior to trial. Weeks v. United States, 232 U.S. 383 (1914); Garhart v. United States, 157 F.2d 777 (10th Cir. 1946). This rule was later changed to permit the motion at the trial where the fact of seizure was first known at the trial. Gouled v. United States, 255 U.S. 298 (1921). The present federal rule is that the trial court may accept an application made for the first time at trial, despite previous knowledge. FED. R. CRIM. P. 41(e); United States v. Di Re, 159 F.2d 818 (2d Cir. 1947), aff'd 332 U.S. 581 (1948). Failure to object at the trial to the reception in evidence of the products of an unlawful search is fatal to a consideration of the objection on appeal in both military and federal courts. United States v. Dupree, 5 C.M.R. 93, 97 (Ct. of Mil. App. 1952) ; Butler v. United States, 153 F.2d 993 (10th Cir. 1946) ; Morton v. United States, 147 F.2d 28 (D.C. Cir. 1945), cert. denied, 324 U.S. 875 (1945).

30. United States v. Dupree, 5 C.M.R. 93, 96 (Ct. of Mil. App. 1952) (since the rule which excludes from evidence the product of an unlawful search "is derived from the Federal practice, it may be inferred that all-certainly most-of the restrictions imposed on its application in a civilian setting will be operative in the area of courts-martial procedure.")

31. United States v. Doyle, 4 C.M.R. 137, 139 (Ct. of Mil. App. 1952).

32. United States v. Rabinowitz, 339 U.S. 56, 63 (1950).

33. Thus it is apparent that while the federal rules are the measuring stick in the military courts, the same results will not necessarily obtain. So far all federal cases involving military searches have found them reasonable. E.g., Best v. United States, 184 F.2d 131 (Ist Cir. 1950), cert. denied, 340 U.S. 939 (1951) ; Richardson v. Zuppann, 81 F. Supp. 809 (M.D. Pa. 1949), aff'd, 174 F.2d 829 (3d Cir. 1949); Romero v. Squier, 133 F.2d 528 (9th Cir. 1943), cert. denied, 318 U.S. 785 (1943); Grewe v. France, 75 F. Supp. 433 (E.D. Wis. 1948). But cf. United States v. Florence, 5 C.M.R. 48, 51 (Ct. of Mil. App. 1952).

34. 4 C.M.R. 137 (Ct. of Mil. App. 1952). 
tion ${ }^{35}$ dealt with searches and seizures of an automobile without a warrant; each of these cases relied on Carroll $v$. United States, ${ }^{36}$ which upheld a search without a warrant because the vehicle might be moved out of the locality or jurisdiction in which the warrant might be sought.37 The Doyle case did not involve a search under circumstances demanding immediate action to prevent the removal or disposal of property believed on reasonable grounds to be criminal goods, ${ }^{38}$ because the accused had been arrested as a result of another incident and was under guard. ${ }^{39}$ It has been said that "what would constitute probable cause justifying the search of an automobile might be wholly insufficient to authorize the search of one's dwelling place. . . " 40 The barracks and assigned locker space have been interpreted as constituting a soldier's dwelling place. ${ }^{41}$ Therefore, the locker search in the Doyle case appears to have been unreasonable, at least on principle.

The "existing military and navy law" to which the Court of Military Appeals referred in holding the search reasonable appears to have been more correctly analyzed by the Board of Review in the Kofnetka case, ${ }^{42}$ which also involved a search upon information from an eyewitness that accused had stolen property in his locker. The Board of Review, although finding the evidence admissible because conducted by an acting commanding officer who had authority to order a search, rejected the contention that an adjutant's search was lawful when based on an eyewitness' report. The Board stated that ". . . except for cases involving a search of a motor vehicle without a warrant, but upon probable cause based on reasonable grounds . . . the fact that. a Federal official making a search acts on reliable information or complaint as to the commission of an offense, does not dispense with the necessity for obtaining proper authorization to conduct the search, particularly when a dwelling house or a building in the nature of a dwelling is involved. . . . Assuming . . . reliable informa-

35. Brinegar v. United States, 338 U.S. 160 (1949); Gilliam v. United States, 189 F.2d 321 (6th Cir. 1951); Pearson v. United States, 150 F.2d 219 (10th Cir. 1945).

36. 267 U.S. 132, 158 (1925).

37. This type situation is expressly provided for in the Mannal by one of the listed examples of a lawful search. See text at note 83 .

38. Cf. MEM. OpInIons of JAGA (1949-50) 352 (search of bag carried by accused at night in a black-marketing area after misleading response to question of MP concerning contents of bag, held legal because not unreasonable under Fourth Amendment) ; BuLlEtin of JAGA, VoL. II $1943 \$ 264$ (search of automobiles leaving military post upon well-founded reports they were being used to remove government property, held reasonable).

39. Even an automobile cannot be searched without a warrant where the owner is in jail. Hart v. United States, 162 F.2d 74 (10th Cir. 1947).

40. Pearson v. United States, 150 F.2d 219, 220 (10th Cir. 1945).

41. United States v. Kofnetka, 2 C.M.R. 773, 779 n.6 (AF Bd. of Rev. 1952) (airman may assert an objection to a search without his consent and without proper authorization of the locker space assigned to him in a government barracks in which he is quartered, unless it is a search made in accordance with military custom or is a routine formation).

42. United States v. Kofnetka, supra note 41. 
tion, or even probable cause . . . in making his search, it is clear that the wall locker searched in this case does not fall within the exception of the motor vehicle cases . . . where immediate action is necessary. There were no special considerations shown in regard to accused's wall locker which would have rendered futile a search conducted after a delay long enough to have procured authorization for the particular search from the commanding officer." The federal rule exempts obtaining a search warrant only where the search is incident to a valid arrest ${ }^{43}$ or in extraordinary or exceptional circumstances ${ }^{44}$ making it impractical to secure a search warrant through orderly procedure. ${ }^{45}$ The burden is on those seeking the exemption to show the need for it. ${ }^{46}$ Applying these same rules to the Doyle case, it seems that that search was unreasonable because no exceptional circumstances were shown, concerning the stolen goods in the locker belonging to the accused, which would authorize a search without a warrant. Since in federal courts the decision as to when the right of privacy is to yield to the right of search is generally made by a responsible judicial officer, it would appear proper that the question of when the right of privacy in a sailor's locker is to yield to the right of search should be answered by a responsible officer and not by a disciplinary representative as the Doyle case permits. ${ }^{47}$

By limiting the inadmissibility to unlawful searches "conducted or instigated by persons acting under authority of the United States" the Manual, like the rules of the federal courts, does not exclude evidence obtained as a result of an unlawful search or seizure by private persons or state officers if made independent of any co-operation with federal or military officers. ${ }^{48}$

43. United States v. Rabinowitz, 339 U.S. 56 (1950) (whether a warrant is required before making a search after a lawful arrest depends upon the reasonableness of the search rather than solely upon the practicability of procuring a search warrant).

44. But cf. Johnson v. United States, 333 U.S. 10 (1948) (detecting odor of opium coming from accused's hotel room is not a sufficiently exceptional circumstance to legalize a search without a warrant).

45. United States v. Jeffers, 342 U.S. 48 (1951) (reason to believe narcotics law was being violated is not sufficient to authorize a search of hotel room even though narcotics were found); Steeber v. United States, 198 F.2d 615 (10th Cir. 1952).

46. United States v. Jeffers, 342 U.S. 48 (1951) ; McDonald v. United States, 335 U.S. 451 (1948).

47. This is particularly true when in cases of searches occurring within a military installation the power to authorize and to execute are in the commanding officer. See note 16 silpra.

48. Burdeau v. McDowell, 256 U.S. 465 (1921) (constitutional guaranties against unreasonable searches and seizures not violated where incriminating papers introduced as evidence were stolen by private persons who turned them over to federal authorities); Weeks v. United States, 232 U.S. 383 (1914) (Fourth Amendment not applicable to unauthorized seizures of papers and property by municipal police officers not acting under any claim of federal authority); Cannon v. United States, 166 F.2d 85 (5th Cir. 1948) (evidence illegally obtained by state prohibition agents admissible in federal prosecution). But cf. Lustig v. United States, 338 U.S. 74, 78 (1949) (it is a search by a federal official if he participated in it before the object of the search was completely accomplished); Byars v. United States, 273 U.S. 28, 32 (1927) (a federal search exists where federal prohibition agent assisted state officers when requested, hoping that something would be disclosed of official interest to him). 
Thus an unauthorized search of an accused's locker by a private first class ${ }^{40}$ or other noncommissioned officer ${ }^{50}$ made for the purpose of recovering his property, rather than by disciplinary or law enforcement agents, is not within the rule making evidence obtained thereby inadmissible in a courtmartial. But if the unauthorized search is made by members of a law enforcement agency acting in that capacity the evidence obtained is inadmissible. ${ }^{51}$ Since both commissioned and noncommissioned officers are charged generally with certain responsibilities and authority, any searches made by them while acting in that capacity and for the best interests of the service would be under authority of the United States. ${ }^{52}$ If the accused were to acquiesce in a superior's demands or orders, given for the purpose of recovering the superior's own property, it would be only reasonable to consider it as under authority of the United States. To hold otherwise would permit use of disciplinary authority as a subterfuge for evading this exclusionary rule of evidence.

Wiretapping.-There have been no opinions dealing with the inadmissiblity of evidence obtained as a result of "wiretapping" in courtsmartial, but the history of the preparation of the Manual shows that no attempt was made to lay down any independent military rules to be followed by courts-martial with respect to this evidence. Thus, resort must be made to the federal law ${ }^{\mathbf{5 3}}$ which "appears to rest solely upon a statutory foundation which may be shaken in the future by amendatory legislation." 54

Fruits of an Illegal Search.-Not only is evidence obtained by illegal searches and seizures inadmissible in courts-martial, but again paralleling the federal rules," 55 the $M a m u a l$ provides that "all evidence obtained through information supplied by such illegally obtained evidence is likewise inadmissible." This policy of preventing the subversion of the search and

49. United States v. Kofnetka, 2 C.M.R. 773, 778 (AF Bd. of Rev. 1951). This private first class was the eye witness referred to in text at note 42 .

50. United States v. Moorlegham, 4 C.M.R. (AF) 549, 552 (AF Bd. of Rev. 1951); cf. United States v. Gilbert, 5 C.M.R. 708 (AF Bd. of Rev. 1952).

51. United States v. Thomas, 4 C.M.R. 729, 732 (AF Bd. of Rev. 1952) (CID agent); United States v. Cook, 1 C.M.R. 850, 853 (AF Bd. of Rev. 1951) (OSI agent); United States v. Bundy, 2 C.M.R. (AF) 809, 816 (AF Bd. of Rev. 1950) (air policeman).

52. United States v. Gosnell, 3 C.M.R. 646, 658 (AF Bd. of Rev. 1952) (search by officer as "Officer of the Day" illegal); United States v. Darby, 2 C.M.R. (AF) 200 (AF Bd. of Rev. 1949) (officer calling at accused's residence to secure accused's military issue uniform for use in the stockade in accordance with routine procedure was acting under authority of the United States).

53. Nardone v. United States, 308 U.S. 338 (1939), appears to be the clearest expression of the federal rule, which is that any evidence by federal officers as to interstate communications intercepted by the tapping of telephone or telegraph wires is inadmissible in a federal court because of the provisions of the Federal Communications Act of 1934 which prohibit any person not authorized by the sender from intercepting any communication and divulging or publishing the contents, substance, purport, effect or meaning of such intercepted communication to any person.

54. Legal and Legrslative Basis, M.C.M., 1951240.

55. Silverthorne Lumber Co. v. United States, 251 U.S. 385 (1920), states that illegally obtained evidence shall not be used at all. 
seizure rule by indirection has been consistently followed. Thus subsequent confessions dealing with the property illegally seized ${ }^{56}$ and testimony regarding an illegal search ${ }^{57}$ have been held inadmissible. Under the prior Manual for Courts-Martial, 1949, where the provisions were not so explicit, it had been held that evidence obtained by a commanding officer's search was admissible regardless of the source of information which impelled him to make the search. ${ }^{58}$ This interpretation is changed under the present Manual where "the admissibility of evidence obtained by a search made or authorized by a commanding officer may not be determined wholly apart from the information which prompted it." 59 The courts-martial like the federal courts have recognized an exception in applying the basic rule that illegally obtained evidence shall not be used at all. Where the same evidence is obtained independently from both a lawful source and an unlawful source, such evidence is admissible. ${ }^{60}$ Thus, government property seized by government agents under a valid search warrant is admissible in courtsmartial despite a prior illegal search revealing the same property, where the second search was based on information from independent sources known prior to the first illegal search. ${ }^{61}$

\section{Examples of Lawful Searches}

In addition to proscribing generally the use of evidence obtained by means of unlawful searches, the Manual lists specific examples of searches which are to be considered lawful for the purpose of admitting the evidence obtained thereby.

II 152 provides that "a search conducted in accordance with the authority granted by a lawful search warrant" is a lawful search. Such a search has always been considered lawful in court-martial cases, although there is a difference between on-post and off-post searches. ${ }^{62}$ In off-post

56. United States v. Cook, 1 C.M.R. 850, 853 (AF Bd. of Rev. 1951) (accused's pretrial statement inadmissible because obtained as a result of exhibiting the proceeds of an illegal search and is therefore touched by the same taint of illegality); United States v. Edwards, 3 C.M.R. (AF) 540, 544 (AF Bd. of Rev. 1950) (accused's confession dealing, with property illegally seized as a result of an unlawful search held inadmissible in evidence) ; United States v. Darby, 2 C.M.R. (AF) 200, 206 (AF Bd. of Rev. 1949) (evidence of voluntary confession inadmissible since inculpatory statements stemmed from an illegal search and seizure).

57. United States v. Thomas, 4 C.M.R. 729, 732 (AF Bd. of Rev. 1952) (testimony of CID agent' with reference to an unlawful search of accused held inadmissible). But cf. United States v. Rhodes, C.M. 354858 (A Bd. of Rev., Sept. 8, 1952) (statement made that the preceding unlawful search referred to in the Manual, see text at note 28 supra, means wire tapping).

58. United States v. Worley, 3 C.M.R. (AF) 424 (AF Bd. of Rev. 1950).

59. United States v. Kofnetka, 2 C.M.R. 773, 778 (AF Bd. of Rev. 1952).

60. Silverthorne Lumber Co. v. United States, 251 U.S. 385 (1920), recognizes that evidence obtained in this fashion does not become inaccessible, because where "knowledge of them is gained from an independent source they may be proved like any others."

61. United States v. Allen, 3 C.M.R. (AF) 33 (AF Bd. of Rev. 1950).

62. See note 16 supra. For the purposes of this discussion, "on-post" will be used to indicate on an armed forces post, station or reservation in the United States and "off-post" will be used to indicate outside such areas. 
searches of military personnel and their property the general civil requirements obtain. ${ }^{63}$ If the off-post search is made by state officials alone, without such cooperation of federal or armed forces personnel as to make it a federal search, ${ }^{64}$ any evidence obtained is admissible, since, regardless of the validity of the state warrant, the search was not made by persons acting under authority of the United States. ${ }^{65}$ A lawful federal or state search warrant which would authorize a federal or military off-post search in the United States must be based upon an affidavit of reasonable grounds and the application must conform to the federal standard required for search warrants. ${ }^{66}$ Thus, a federal agent may lawfully obtain and use a state search warrant providing the federal standards are met, ${ }^{67}$ or he may obtain and use a federal search warrant issued by the federal district court having jurisdiction of the area to be searched. ${ }^{68}$

If an on-post search is made under authority of a search warrant instead of being authorized by a commanding officer, a federal search warrant would probably have to be obtained unless the state's reserved right to serve civil and criminal process within federal areas purchased with its

63. Digest of OPINIONS of JAGA, 1912-1940 \&395(27) (C.M. 161760 1924); (1941); BuLletiN of JAGA, Voc. III, 1944, 512 (C.M. 264149 1944); United States v. Darby, 2 C.M.R. (AF) 200, 204 (AF Bd. of Rev. 1949).

64. Mere participation in a state search by a federal agent as a private person and not as a federal enforcement agent does not render it a federal undertaking, but when the federal agent participates under color of his federal office the search is a joint operation of the local and federal officers. See note 48 supra. The fact that military personnel accompany civil police to identify the government property for which the state search warrant was issued does not render it an illegal search and seizure. Richardson v. Zuppann, 81 F. Supp. 809 (M.D. Pa. 1949), aff'd, 174 F.2d 829 (3d Cir. 1949) (proper for police duly authorized to make a search to take along military persons for identification of the property for which the warrant was issued); Romero v. Squier, 133 F.2d 528 (9th Cir. 1943), cert. denied, 318 U.S. 785 (1943) (army agent accompanied Philippine police to identify secret U.S. Army maps for which valid search warrant had been issued).

65. United States v. Gilbert, 5 C.M.R. 708 (AF Bd. of Rev. 1952).

66. FED. R. CRIM. P. 41. Weinberg v. United States, 126 F.2d 1004 (2d Cir. 1942) (to justify a search by federal officers, it is necessary to obtain a warrant from a proper official upon probable cause supported by affidavit, naming or describing person and particularly describing property and place to be searched, and the warrant must state probable cause for its issue, names of persons whose affidavits were taken in support of it, the place to be searched, and the persons or things to be seized). United States v. Whitler, 5 C.M.R. 458, 462 (AF Bd. of Rev. 1952); United States v. Allen, 3 C.M.R. (AF) 33, 40 (AF Bd. of Rev. 1950) (search by OSI agent under federal search warrant held lawful); United States v. McKinney, 1 C.M.R. (AF) 625, 635 (AF Bd. of Rev. 1949) ; Harris v. United States, 117 F.2d 988 (6th Cir. 1941). In cases of federal searches under state search warrants it is not necessary to inquire whether the warrant was good under state law where the requirements for a federal search warrant are not met. Byars v. United States, 273 U.S. 28, 29 (1927). Search warrants procured in accordance with the requirements of the local foreign law will authorize military searches of residences of armed forces personnel which are located in friendly foreign countries and not within the confines of any military reservation, even though the warrants are obtained "by information on oath" rather than by affidavits of reasonable grounds. United States v. Whitler, 5 C.M.R. 458, 464 (AF Bd. of Rev. 1952).

67. United States v. Darby, 2 C.M.R. (AF) 200 (AF Bd. of Rev. 1949).

68. Cf. Weinberg v. United States, 126 F.2d 1004 (2d Cir. 1942) (search and seizure of property in Southern District of New York illegal where made pursuant to order of federal district court in Michigan). 
consent is interpreted to include issuance of a search warrant. ${ }^{69}$ The interplay between federal and state areas is illustrated by a case where civilian police obtained a warrant (presumably a state warrant) to search a car which they believed contained stolen seat covers and which belonged to a sailor who was already under naval arrest. A stolen master-at-arms' badge was found in the car during the search which occurred outside the naval station while both the accused and the station master-at-arms were present. ${ }^{70}$ The Court of Military Appeals held this evidence admissible because it was seized during a search conducted under the authority of a lawful state search warrant. If the car was actually on property within the federal area, possibly the state warrant was not valid because it might not have been within the right reserved to the state over the federal area. Even if the search was conducted off-post, if there was sufficient participation by the master-at-arms to make it a federal search, ${ }^{71}$ the court should have determined whether in the issuance of the state search warrant the federal requirements were met.

A second example of a lawful search is:

"A search of an individual's person, of the clothing he is wearing, and of the property in his immediate possession or control, conducted as an incident of lawfully apprehending him."

This example is listed for the first time in the present Manual, but the principle involved has long been assumed by the military. ${ }^{72}$ Actually it is nothing more than an adaptation of the federal rules of the Harris and Rabinozvitz cases ${ }^{73}$ to military terminology-apprehension instead of arrest. In other sections of the Manual, apprehension is defined as the taking into custody of a person and it may be effected by clearly notifying the person to be apprehended that he is thereby taken into custody. Custody is that restraint of free locomotion caused by corporeal and forcible taking into custody or by that "control exercised in the presence of the prisoner by official acts or orders." 74 The control exercised by an officer's official

69. For discussion of jurisdiction within federal areas see Note, Federal Areas: The Confusion of a Jurisdictional-Geographical Dichotomy, 101 U. of PA. L. REv. 124 (1952).

70. United States v. Doyle, 4 C.M.R. 137, 141 (Ct. of Mil. App. 1952). A1though the report states the search occurred outside the station it is not clear whether it was actually on government property because parking areas are frequently provided for naval personnel outside the gates and fence of the naval station. These areas are still on government property because they are within the territory purchased from the state.

71. See note 64 supra. But cf. Lustig v. United States, 338 U.S. 74 (1949); Cannon v. United States, 166 F.2d 85 (5th Cir. 1948) (no participation either active or tacit); United States v. Brown, 8 F.2d 630 (D.C. Ore. 1925) (federal officers not present to assist).

72. Meno. Opinions of JAGA 1949-50 368.

73. United States v. Rabinowitz, 339 U.S. 56 (1950) (search of one room office lawful when incident to arrest); Harris v. United States, 331 U.S. 145, 151 (1947) (search without a warrant which was incident to an arrest may extend beyond the person to include the premises under his immediate control).

74. See United States v. Gosnell, 3 C.M.R. 646, 650 (AF Bd. of Rev. 1952). 
order to an airman to accompany the officer to the airman's barracks has been held sufficient apprehension under this example of a lawful search. ${ }^{75}$ The Court of Military Appeals and the boards of review, following the federal cases, ${ }^{76}$ have been alert to require probable cause for apprehending the accused and to prevent the apprehension from being used as a subterfuge to make a search without a warrant. ${ }^{77}$ Where CID agents raiding a Japanese hotel for violations of the narcotics law found a hypodermic needle and syringe in accused's uniform jacket hanging on a wall hook, an unlawful search and seizure resulted since the accused was not lawfully apprehended until after the search and there was no probable cause for taking the accused into custody until after the discovery of the contraband goods. ${ }^{78}$ Military searches were found not incident to an arrest and therefore unlawful where an OSI agent told the accused to step outside to the agent's jeep and empty his pockets, ${ }^{79}$ and where an accused had been held in arrest by a town marshal for more than two hours before the search was made by the Air Police. ${ }^{80}$ The meaning of the term "property in his immediate possession or control" was narrowly construed so as to hold illegal a search of accused's wall locker in his barracks, because the barracks were not within accused's immediate possession or control when he was apprehended in a latrine building located fifty yards from the barracks. ${ }^{81}$ Whether or not the latrine is to be considered essential to everyday living in the barracks so as to include both within the concept of a "house" or "living quarters," this decision is typical of the extreme care taken by some boards of review ${ }^{82}$ to protect the accused where search and seizure problems have arisen.

The third listed example of a lawful search is:

"A search under circumstances demanding immediate action to prevent the removal or disposal of property believed on reasonable grounds to be criminal goods."

This is an adoption of the federal rule which permits a search of a motor vehicle without a warrant, when performed upon probable cause based

\section{Ibid.}

76. Johnson v. United States, 333 U.S. 10, 16 (1948) (". . . the Government is obliged to justify the arrest by the search and at the same time to justify the search by the arrest. This will not do.") ; McKnight v. United States, 183 F.2d 977 (D.C. Cir. 1950) (arrest based on warrant does not authorize search when arrest is mere pretext for search).

77. United States v. Florence, 5 C.M.R. 48, 53 (Ct. of Mil. App. 1952) ; cf. United States v. Ward, 2 C.M.R. 688 (AF Bd. of Rev. 1951) (where accused was apprehended attempting to leave the base with a false pass and there were several indications that the automobile he was driving was stolen, a search of the automobile glove compartment was held incident to a legal arrest).

78. United States v. Thomas, 4 C.M.R. 729 (AF Bd. of Rev. 1952).

79. United States v. Cook, 1 C.M.R. 850 (AF Bd. of Rev. 1951).

80. United States v. Bundy, 2 C.M.R. (AF) 809 (AF Bd. of Rev. 1950); accord, United States v. Edwards, 3 C.M.R. (AF) 540 (AF Bd. of Rev. 1950).

81. United States v. Gosnell, 3 C.M.R. 646 (AF Bd. of Rev. 1952). Contra:

United States v. Stein \& Sizemore, C.M. 349776 (A Bd. of Rev., Apr. 28, 1952).

82. See text at note 33 supra. 
on reasonable grounds..$^{83}$ The boards of review have indicated that the words "under circumstances demanding immediate action to prevent the removal or disposal of property" will be narrowly interpreted. ${ }^{84}$ A typical position was taken in United States $v$. Thomas ${ }^{85}$ where the evidence indicated that during a narcotics raid accused's uniform jacket was searched. The Board of Review finding "no invitation to search, no consent, no attempt at flight, no threat to dispose of the implements-no reason at all why permission to search could not have been obtained from proper authority" held the search unlawful. This decision is analogous to Johnson $v$. United States, ${ }^{86}$ where the Supreme Court held illegal a search without a warrant where a federal agent detected the odor of burning opium coming from a hotel room and entered without a search warrant. The requirement that the property must be "believed on reasonable grounds to be criminal goods" eliminates the subterfuge of asking without good cause for a soldier to give his consent to a search and if he refused, then to claim that circumstances demanded immediate action to prevent the removal of property. ${ }^{87}$ It has been stated that "the test of whether [the conditions listed in the third example] . . . have been met is determined objectively after the search is made and in view of all of the known circumstances existing at that time. The test will never be a subjective determination of how the situation appeared to the person making the search at the time of the search." 88

A similar treatment has been given to another example of a lawful search listed in the Manual:

"A search made with the freely given consent of the owner in possession of the property searched."

There probably is more reason to question consent to a search given by a soldier to a superior in military life than where consent is given by a civilian

83. Brinegar v. United States, 338 U.S. 160 (1949) (search of automobile without a warrant but upon probable cause that the law is being violated held lawful); Carroll v. United States, 267 U.S. 132, 158 (1925) (search without a warrant of a vehicle which may be moved out of the locality or jurisdiction is lawful). But cf. Steeber y. United States, 198 F.2d 615 (10th Cir. 1952).

84. United States v. Gosnell, 3 C.M.R. 646, 657 (AF Bd. of Rev. 1951) (search unlawful where accused in custody of air police and air police are available to prevent access by accomplices to locker); United States v. Kofnetka, 2 C.M.R. 773,779 (AF Bd. of Rev. 1952) ("no special considerations shown in regard to accused's wall locker which would have rendered futile a search conducted after a delay long enough to have procured authorization for the particular search from the commanding officer.") ; United States v. Cook, 1 C.M.R. 850, 853 (AF Bd. of Rev. 1951) (although "accused was in the 'MATS terminal' [airport] when confronted by the OSI agent, there was no showing that he was about to leave Eniwetock Atoll so that immediate action was necessary"); United States v. Bundy, 2 C.M.R. (AF) 809, 816 (AF Bd. of Rev. 1950) (immediate action not imperative where accused was previously in town-marshal's custody for three hours and vehicle was not under accused's immediate control).

85. 4 C.M.R. 729 (AF Bd. of Rev. 1952).

86. 333 U.S. 10 (1948).

87. Accord, United States v. Trolinger, 5 C.M.R. 447, 452 (AF Bd. of Rev. 1952) ; United States v. Thomas, 4 C.M.R. 729, 732 (AF Bd. of Rev. 1952).

88. United States v. Gosnell, 3 C.M.R. 646, 657 (AF Bd. of Rev. 1952). 
to a police officer; a soldier generally realizes that his superiors have a stronger grip on his future in the way of promotions and type of duty assignments, and there exists a general misconception as to the limits of a superior's authority. Courts-martial as well as federal courts ${ }^{80}$ do not readily find actions of an accused that constitute consent to a search of private property and homes. In United States $v$. Kofnetka ${ }^{80}$ there was held to be no voluntary consent by the accused to two searches since he did not know of them, and to a third search because he was "informed by the commanding officer that the latter intended to make the third one." It was stated: "Consent to a search is not lightly to be implied merely because a person peaceably submits, either to what he believes to be a lawful search, or to a show of force or authority." The cases indicate that "freely given consent" will not be readily found. ${ }^{91}$

The concluding example of a lawful search is stated by the Manual as:

"A search of property which is owned or controlled by the United States and is under the control of an armed force, or of property which is located within a military installation or in a foreign country or in occupied territory and is owned, used, or occupied by persons subject to military law or to the law of war, which search has been authorized by a commanding officer (including an officer in charge) having jurisdiction over the place where the property is situated or, if the property is in a foreign country or in occupied territory, over personnel subject to military law or to the law of war in the place where the property is situated. The commanding officer may delegate the general authority to order searches to persons of his command. This example of authorized searches is not intended to preclude the legality of searches made by military personnel in the areas outlined above when made in accordance with military custom."

89. Amos v. United States, 255 U.S. 313 (1921); Gouled v. United States, 255 U.S. 298 (1921); United States v. Lantrip, 74 F. Supp. 946, 949 (E.D. Ark. 1948) ; United States v. Sully, 56 F. Supp. 942 (S.D.N.Y. 1944). But cf. Davis v. United States, 328 U.S. 582 (1946); Zap v. United States, 328 U.S. 624 (1946); United States v. Pugliese, 153 F.2d 497 (2d Cir. 1945).

90. 2 C.M.R. 773, 777 n.1 (1951).

91. United States v. Heck, C.M. 354324 (A Bd. of Rev., Oct. 9, 1952) (no consent where officer was informed of the intent of military police to conduct a raid and he said "yes" and stepped aside to permit them to enter the officer's quarters); United States v. Cook, 1 C.M.R. 850, 853 (AF Bd. of Rev. 1951) (no consent where accused was "more or less ordered" to empty his pockets and where he thought OSI agent had authority to require him to submit to the search); United States v. Jones, 4 C.M.R. (AF) 218, 221 (AF Bd. of Rev. 1950) (unauthorized OSI agent asked accused if he would open his footlocker; when accused made no reply but did open the footlocker, held, no consent given by accused). But cf. United States v. Johnson, 2 C.M.R. 644 (AF Bd. of Rev. 1951) (acquiescence to policeman's visit when accused was peaceably submitting to what he believed to be a lawful seizure was not implied consent to seizure but was consent to search and evidence is admissible because policeman could have testified to what he saw); United States v. Cornell, 2 C.M.R. (AF) 121, 125 (AF Bd. of Rev, 1949) (where accused led OSI agent to closet after agent merely inquired about the presence of any government property, held, a voluntary consent or invitation to the search of the closet). 
No doubt most searches are made under this example. The cases construing the prior Manual, which made no mention of delegations, held that delegations of the commanding officer's authority were not permitted.92 However, the term commanding officer included lower unit commanders with respect to searches in areas allocated to and set apart for the lower units. $^{93}$ Under the present Manual there are limitations on the authority of the commanding officer to delegate this authority to order searches. Thus, the Air Force Judge Advocate has stated that ". . . a 'delegation' to each and every member of a squadron of Air Force policemen, could not be sanctioned ..." and a delegation of ". . . the general power to order searches to individuals primarily engaged in criminal investigative or police work" would be undesirable and illegal. ${ }^{94}$ Both express and implied delegations to squadron adjutants of the general authority to conduct searches have been found reasonable delegations of authority. ${ }^{95}$

Although the Manual does not specifically require that the commanding officer's exercise of the power to order a search be based upon reasonable grounds, the language in the cases and the statement of the Air Force Judge Advocate clearly dictate this requirement. For example, the Air Force Judge Advocate, in noting that a person to whom authority to order a search has been delegated has the same authority to make the search himself which the commanding officer had prior to the Mamual, said: "The former requirement for the exercise of the responsible official's [commanding officer] discretion in each case remains." Of particular note is the indication that delegation should be restricted to those few persons "not inflamed by the heat of the chase" whose rank, experience, position of trust, responsibilities and discretion "ensure dispassionate and impartial consideration in determination of the exercise of the delegated power." 96 The Court of Military Appeals has neatly avoided delimiting the extent of the commanding officer's power to authorize a search. In the Doyle case, after referring to the differentiation between the power of a commanding officer over military property and the power of a police officer to invade a citizen's privacy, that court stated: "That there may be limitations upon the former's power, we do not doubt. Insofar as the power bears on criminal prosecutions, both trial courts and appellate forums are available to insure that the commanding officer does not abuse his discretion to

92. United States v. Jones, 4 C.M.R. (AF) 218, 221 (AF Bd. of Rev. 1951) (commanding officer may not delegate his authority to authorize searches under M.C.M., 1949) ; United States v. Hopkins, 4 C.M.R. (AF) 553, 560 (AF Jud. Council 1951) (commanding officer may not give a "blanket authorization" to make searches under M.C.M., 1949).

93. United States v. Jones, 4 C.M.R. (AF) 218, 220 (AF Bd. of Rev. 1951).

94. These statements are reported in United States v. Taylor, 1 C.M.R. 847, 849 (AF Bd. of Rev. 1951).

95. United States v. Kofnetka, 2 C.M.R. 773, 780 (AF Bd. of Rev. 1952); United States v. Taylor, 1 C.M.R. 847, 850 (AF Bd. of Rev. 1951).

96. See United States v. Taylor, 1 C.M.R. 847, 849 (AF Bd. of Rev. 1951) (italics added). 
the extent that the rights of an individual are unduly impaired." ${ }^{97}$ The most recent search case decided by the Court of Military Appeals again finds that court staying on the fence. ${ }^{98}$ In referring to prior court-martial cases dealing with the plenary power of the commanding officer to order searches, the court stated: "These authorities show good reasons, and many others are suggested, as to why a seizure rule different from the one prescribed for civilians is necessary in the military service. However, the Manual for Courts-Martial, United States, 1951, treats more fully with search and seizure and it may be the foundation for curtailing a commanding officer's powers. For that reason at this time, we neither adopt nor reject the former rule because in this instance the commanding officer's conduct did not breach civilian principles. We are attempting to carry out the congressional intent to grant to military personnel, whenever reasonably possible, the same rights and privileges accorded civilians." In keeping with its desire to mold a pattern of rights which are labeled "military due process," 98 the Court of Military Appeals when squarely faced with the issue will probably decide that the exercise by the commanding officer of his power to authorize military searches must be based upon reasonable grounds. ${ }^{100}$

The example under discussion makes lawful those searches, when authorized by a commanding officer, of the following property: that owned or controlled by the United States and under the control of an armed force; that located within a military installation and owned or used by persons subject to military law. ${ }^{101}$ This gives a broad power to the commanding officer which, if literally interpreted, would legalize searches of the uniform and equipment being worn by persons subject to military law as well as most other property on a military post. ${ }^{102}$ In the past the Judge Advocate, the Judicial Council, and the boards of review have assumed that the commanding officer, in the exercise of sound discretion, has authority to search the person of a member of the military establishment because such authority is indispensable to the maintenance of good order and discipline in any military command. ${ }^{103}$ The cases are not put on the grounds that the property searched was being used by persons subject to military law-which

97. United States v. Doyle, 4 C.M.R. 137, 140 (Ct. of Mil. App. 1952).

98. United States v. Florence, 5 C.M.R. 48, 51 (Ct. of Mil. App. 1952).

99. United States v. Clay, 1 C.M.R. 74, 77 (Ct. of Mil. App. 1951).

100. What amounts to reasonable grounds in a military context will have to be determined on an ad hoc basis.

101. Although a search is authorized by a commanding officer under this example, the evidence obtained may be inadmissible if the search was ordered because of information obtained by a prior illegal search. United States v. Kofnetka, 2 C.M.R. 773, 778 (AF Bd. of Rev. 1952).

102. Under the post-World War II supply system changes, enlisted personnel were given a yearly allowance for the purchase of uniforms. The uniforms might then be considered "owned" by them, but still they are controlled by the armed forces to the extent of regulations applicable to uniforms.

103. United States v. Florence, 5 C.M.R. 48, 50 (Ct. of Mil. App. 1952) ; United States v. Rhodes, C.M. 354858 (A Bd. of Rev., Sept. 8, 1952); United States v. Arteaga, 1 C.M.R. 632, 635 (AF Bd. of Rev. 1951). 
would require authority from the commanding officer, probably based upon reasonable grounds. Instead, they hold searches of the person lawful because made in accordance with military custom, ${ }^{104}$ the authority for which may be found in the concluding sentence of this example.

The few court-martial cases which discuss military custom do not clearly define the extent of its application. The legislative history indicates that on military posts the normal civilian rule of search and seizure is not followed because "frequently you could not find anybody to issue a warrant." 105 Another part of the Manual ${ }^{106}$ states: "In its legal sense the word 'custom' imports something more than a method of procedure or a mode of conduct or behavior which is merely of frequent or usual occurrence. Custom arises out of long established practices which by common consent have attained the force of law in the military or other community affected by them. There can be no such thing as a custom that is contrary to existing law or regulation. A custom which has not been adopted by existing statute or regulation ceases to exist when its observance has been long abandoned. Many customs of the service are now set forth in regulations of the various armed forces." A search made in accordance with custom does not require the authority of the commanding officer. ${ }^{107}$ It has been stated that, "Through a devolution of command, certain officers and noncommissioned officers have been authorized by custom to search and order such searches as, for instance, 'a shake-down' search of an entire group of men, or a search for 'overages' of clothing or equipment, or a search of all vehicles leaving a command, and other like instances." 108 Since such searches are generally made periodically and not called for the particular purpose of seeking to discover evidence of a crime, there appears to be no reason why they must be based upon reasonable grounds. There is authority for limiting this type of search made in accordance with military custom to those searches of a whole command or unit in general, and not to include searches directed toward a specific person. ${ }^{109}$ All of the searches mentioned are confined to the barracks or exits of a command; thus the indication is that a search of private family quarters located on a post will not be permitted unless authorized by the commanding officer. However,

104. Ibid.

105. Hearings before Subcommittee of the Conmittee on Armed Services on H.R. 2498, 81st Cong., 1st Sess. 1063 (1949). 134).

106. M.C.M., 1951, $\llbracket 213$ a (dealing with breach of custom in violation of Article

107. United States v. Rhodes, C.M. 354858 (A Bd. of Rev., Sept. 8, 1952) (search in office of staff judge advocate on the authority of that officer who was one of the commanding officer's special staff officers held legal because made in accordance with well recognized customs of the service); United States v. Gosnell, 3 C.M.R. 646, 658 (AF Bd. of Rev. 1951).

108. United States v. Gosnell, 3 C.M.R. 646, 658 (AF Bd. of Rev. 1951).

109. United States v. Edwards, 3 C.M.R. (AF) 540, 543 (AF Bd. of Rev. 1950) : 'Barracks inspections and general 'shakedown' inspections which are not directed toward a specific person or his effects and not called for the purpose in particular of seeking to discover evidence of a crime, are routine formations. . . . [E] vidence turned up during such an inspection is not objectionable upon the ground that it was the subject of an unlawful search and seizure." 
where a staff officer is responsible for every detail relating to the conduct of his office, it has been held that customs of the service authorize the staff officer either to conduct or permit a search of his own office when made upon probable cause. ${ }^{110}$

A recent board of review case ${ }^{111}$ contains a significant statement on the proviso regarding searches made in accordance with military custom: "We believe this proviso was intended to cover and make lawful searches directed by other commanding officers, such as unit commanders, regimental commanders or division commanders, against persons and property under their immediate jurisdiction. To consider the proviso as legalizing all searches conducted within the military establishment would render the Manual's prior provision on the subject of little efficacy." Thus, it is relatively certain that neither a search directed at an individual alone without the consent of the commanding or responsible staff officer nor a disguised search of the whole unit conducted for the purpose of making the individual search will be held lawful under the guise of military custom. Possibly such practices are a method of procedure or mode of conduct of frequent occurrence, but even so, it is not a long established practicé which by common consent has attained the force of law in the military community. ${ }^{112}$ Even in searches of an individual's person or equipment by the commanding officer or responsible staff officer, what little authority there is seems to require such searches to be based upon probable cause or ordered in the exercise of discretion. ${ }^{113}$ If searches of the person based upon custom are upheld without such a limitation, military personnel in reality would have little protection from unreasonable searches while on a military reservation. For example, in case of a theft in a unit where one individual is suspected, but there does not exist reasonable grounds upon which the commanding officer could authorize a search of the individual, the unit commander would merely have to order a "shake-down" inspection of the whole unit to have the individual searched during the detailed search of all the members of the unit. No doubt the armed forces will continue to claim the authority to search a soldier's person, as well as his effects, when made in accordance with military custom. Although such a claim is consistent with the definition of custom laid down in the Manual, it could easily be decided otherwise by noting that if the President intended to give such a large grant of authority to make a search of a soldier's person without apprehending him it would have specifically been stated and not left to be implied from such a vague cover-all term as "military custom." The fact that a search of an individual's person when conducted as an incident of lawfully apprehending him was specifically given as an example of a lawful search tends to give further support to the idea that a search of in individual's person was not intended to be authorized under the guise of military custom.

110. United States v. Rhodes, C.M. 354858 (A Bd. of Rev., Sept. 8, 1952).

111. United States v. Heck, C.M. 354324 (A Bd. of Rev., Oct. 9, 1952).

112. See text at note 107 supra.

113. See note 103 supra. 


\section{SuMMaRY}

The rules of search and seizure applied in courts-martial are not bottomed on any constitutional rights. These rules are patterned after and generally follow the federal rules on the subject except for the plenary power given the commanding officer and the legality of searches made solely in accordance with military custom. Unfortunately the Court of Military Appeals does not appear inclined to follow the careful distinctions and narrow interpretations set forth by the boards of review in order to protect the interests of the accused. It is well to remember that all these rules are dealing with admissibility of evidence and probably the reason for generally construing them narrowly is that military personnel are not likely to take the chance of resisting a superior's orders during a search of property. Under the design and application of these rules, armed forces personnel are not forced to resist illegal searches and seizures to secure protection during a trial, because evidence obtained as a result of information secured in an illegal search is not admissible. The only apparent danger is a possible decision that searches of the person made without probable cause are justified as being in accordance with military custom. 